\title{
Forest management and carbon sequestration in wood products
}

\author{
Ingolf Profft · Martina Mund · Georg-Ernst Weber · \\ Eberhard Weller $\cdot$ Ernst-Detlef Schulze
}

Received: 22 February 2008/Revised: 23 February 2009/Accepted: 2 April 2009/Published online: 6 May 2009

(C) The Author(s) 2009. This article is published with open access at Springerlink.com

\begin{abstract}
Wood products are considered to contribute to the mitigation of carbon dioxide emissions. A critical gap in the life cycle of wood products is to transfer the raw timber from the forest to the processing wood industry and, thus, the primary wood products. Therefore, often rough estimates are used for this step to obtain total forestry carbon balances. The objectives of this study were (1) to examine the fate of timber harvested in Thuringian state forests (central Germany), representing a large, intensively managed forested region, and (2) to quantify carbon stocks and the lifetime of primary wood products made from this timber. The analyses were based on the amount and assortments of actually sold timber, and production parameters of the companies that bought and processed this timber. In addition, for coniferous stands of a selected Thuringian forest district, we calculated potential effects of management, as expressed by different thinning regimes on wood products and their lifetimes. Total annual timber sale of soft- and hardwoods from Thuringian state forests (195,000 ha) increased from about 136,893 t C $\left(\sim 0.7 \mathrm{t} \mathrm{C} \mathrm{ha}^{-1}\right.$ year $\left.^{-1}\right)$ in 1996 to $280,194 \mathrm{t} \mathrm{C}(\sim 1.4 \mathrm{t} \mathrm{C}$ $\mathrm{ha}^{-1}$ year $\left.^{-1}\right)$ in 2005 . About $47 \%$ of annual total timber harvest went into short-lived wood products with a mean residence time $(\mathrm{MRT})<25$ years. Thirty-one per cent of the total harvest went into wood products with an MRT of 25-43 years, and only $22 \%$ was used as construction wood
\end{abstract}

Communicated by C. Ammer.

I. Profft $(\bowtie) \cdot$ G.-E. Weber · E. Weller

Thuringian State Institute for Forestry, Game and Fishery,

Jägerstr. 1, 99867 Gotha, Germany

e-mail: Ingolf.Profft@forst.thueringen.de

M. Mund · E.-D. Schulze

Max Planck Institute for Biogeochemistry,

Hans-Knöll-Str. 10, 07745 Jena, Germany and glued wood, products with the longest MRT (50 years). The average MRT of carbon in harvested wood products was 20 years. Thinning from above throughout the rotation of spruce forests would lead to an average MRT in harvested wood products of about 23 years, thinning from below of about 18 years. A comparison of our calculations with estimates that resulted from the products module of the CO2FIX model (Nabuurs et al. 2001) demonstrates the influence of regional differences in forest management and wood processing industry on the lifetime of harvested wood products. To our knowledge, the present study provides for the first time real carbon inputs of a defined forest management unit to the wood product sector by linking data on raw timber production, timber sales and wood processing. With this new approach and using this data, it should be possible to substantially improve the net-carbon balance of the entire forestry sector.

Keywords Harvested wood products . Carbon sequestration - Product lifetime .

Thinning from above . Thinning from below

\section{Introduction}

Wood products are important for the analyses of the mitigation potential of the forestry sector for climate change (Eriksson et al. 2007; Nabuurs et al. 2007). In wood products, carbon is bound until the products decay or until they are burned as waste. In addition, the substitution of manufactured materials (for example steel and alloys) by wood is associated with less emissions of $\mathrm{CO}_{2}$ and other pollutants and less waste during the whole product life cycle compared with alternative materials (Petersen and Solberg 2005; Gustavsson et al. 2006). An important 
contribution to the reduction of $\mathrm{CO}_{2}$ emissions also results from the substitution of fossil fuels by combustion of woody biomass that is not usable for wood products or from the combustion of wood waste (Marland and Schlamadinger 1997). An analysis of the potential contribution of wood products to mitigate $\mathrm{CO}_{2}$ emissions in Switzerland for the years 2000 until 2130 found a considerable potential, especially in the sectors of energy and material substitution (Werner et al. 2006). However, despite the high potential of wood products to contribute to climate change mitigation, data on carbon stocks in wood products in use and on the longevity of these products are rare (e.g. at regional to national scales: Becker and Mellinghoff 1997; Dias et al. 2005; Perez-Garcia et al. 2005; White et al. 2005; at continental scale: Eggers 2002). Also in Germany, where an increase in wood use by $20 \%$ within the next few years is promoted by the governmental "Joint Initiative Charta for Wood" (BMVEL 2004a), a thorough analysis of the fate of harvested wood products has not yet been carried out.

The main reason for this lack of data is the globalisation of timber and wood product markets. It is practically impossible to trace back the trading ways and the lifetimes of imported and indigenous wood after the timber is harvested and sold. Stock-taking of raw materials and wood products, and the possible reuse of wood products at different points in the life cycle are additional factors that make a complete wood product assessment difficult.

In contrast to the previous studies, which focus on the methodology for carbon budgeting of harvested wood products, different modelling approaches, and the climate change mitigation potential of the wood sector in general (e.g. Brown et al. 1998; Winjum et al. 1998; Nabuurs and Sikkema 2001; Karjalainen et al. 2003; Green et al. 2006; Pingoud and Wagner 2006; Woodbury et al. 2007), this study aims to close an important gap in the life cycle of wood products: the transfer of raw timber from the forest to the processing wood industry. This gap is caused by the fact that data sources on timber production in the forest are usually not linked to data on timber sales and processing. Through linking these two data sources, a missing component in the net-carbon balance of the entire forestry sector will be available. Furthermore, our study provides a methodological approach that is needed for wood product models (e.g. Seidl et al. 2007), and for analyses of land management strategies for climate change mitigation (Freibauer et al., submitted; Briceno-Elizondo et al. 2006). The approach can be applied to any forest management unit where, the basic harvesting data are available.

The objectives of this study were:

- to examine the fate of timber wood harvested in Thuringian state forests (central Germany), representing a real, intensively managed forest region,
- to quantify the carbon stocks and lifetime of primary wood products made from timber harvested in state forests of Thuringia [primary wood products $=$ products that are made directly from raw wood and not from other wood products (recycling)],

- to analyse potential effects of different thinning regimes (thinning from below and from above) on the mean lifetime and on carbon stocks of harvested wood products from coniferous stands of a selected Thuringian forest district.

Our approach provides an analysis of the input of carbon into the primary wood sector, or a gross-carbon-balance of a spatially defined forest management unit.

\section{Materials and methods}

Thuringian's state forests

The Thuringian Forestry Administration manages approximately 195,000 ha of forest land owned by the federal state of Thuringia, Germany. The largest parts of the forest are located in a mountain range (between 300 and 1,000 masl) in the south, where geology is dominated by schist and Palaeozoic volcanites, and in the east and west of Thuringia, where limestone forms the dominating bedrock (300-500 masl). Large parts of the region are covered with a loess layer of variable thickness. Soils are dominated by Brown soils, followed by Rendzinas, Podsolic brown soils, and Luvisols (German classification). The climate of Thuringia is characterised by the transition from maritime Western Europe to the continental Eastern Europe. Spruce is the most common tree species covering about $54 \%$ of the forested area. Beech, which grows on $26 \%$ of the forested area, is the most common deciduous tree species. Oak forests account for about $4 \%$, and pine forests for about $16 \%$ of forested area.

\section{Data sources}

The forestry database ABIES-FIS of the Thuringian Forestry Administration includes detailed information on timber type, sale assortments, the first customer and the amount of timber sold since 2001. The sale assortments that are given in the database reflect timber size (diameter and length) and quality. Thus, they provide key information for an assignment to wood product classes (see below).

The database is limited to state forests because of regulations to protect the privacy for private landowners. We restricted our analysis (1) to the main tree species of Norway spruce (Picea abies), Scots pine (Pinus sylvestris), European beech (Fagus sylvatica), and oak (Quercus 
spec.), and (2) to the years 2001 and 2002, which were approximately representative of the last 10 years regarding the distribution of sale assortments, and which were not influenced by a recent structural reform of Thuringian forestry (TMLNU 2006).

Transition from harvested timber to wood products and mean residence times

The sale assortments given in the ABIES-FIS database were grouped into six classes of primary products defined by the same average "mean residence time" (MRT). The grouping and the estimates of the MRT were based on the following data sources:

a. Product classification according to the MRT as proposed by Wirth et al. (2004).

b. An enquiry of the most important wood customers and wood processing industry in Thuringia (Klausner Holz Thüringen, Saalburg-Ebersdorf; Pollmeier Massivholz $\mathrm{GmbH}$, Creuzburg; Rettenmeier Holzindustrie GmbH, Ullersreuth; Zellstoff- und Papierfabrik Rosenthal GmbH \& Co. KG (ZPR), Blankenstein; BHT Bauund Holztechnik Thüringen GmbH, Ebersdorf).

c. Expert estimates given by forestry and industrial experts where information was missing.

The companies that were queried in this study are large national and international companies that dominate the wood industry in Thuringia. They buy the harvested raw timber directly from the land owner (here the state Thuringia), saw the timber, and do all the following wood processing. The companies buy predominantly the amount and quality of timber that they need for their own specific products. Thus, if it is known how much timber is sold to a specific company (as reported in the forestry database ABIES-FIS, see above) then also the fate of the timber is fairly accurately known assuming a true response. The enquiry of the companies included the production process, production yield, and the reuse of waste material.

A central assumption for the classification is that every enterprise is interested in the maximisation of its net revenue so that high quality and more expensive sale assortments are not used for the production of lower value products. This means, for example, that logs sold to a company will be used to produce high quality sawn timber and not comparatively cheap pulp or chips. Fuelwood, on the other hand, can only be used as fuelwood and will not be processed to veneer, but it could be used for pulp. In a few cases (niche products), it is possible that lower sale assortments go into the production of high quality final products, but the quantity is negligible. We further assumed that with the increasing value of the sale assortment, its MRT also increases. The calculations contain the first processing stage with the corresponding losses and the resulting production yield. Material losses occurring thereafter are minor compared with the losses in the first processing stage, and, therefore, were not taken into account. The amount of losses during the first processing and its use depend on both tree species and sale assortment.

We also investigated customer-specific product lines and the lifetime of the resulting products, even though they are not explicitly designated in the sale assortments. This was possible when the designated sale assortments were associated with highly specialised buyers. For example, timber sold as industrial short wood was assigned to saw wood products when it was sold to a customer that only processes saw wood timber. Or, when it is known that a buyer uses Oriented Strand Boards for wood houses, then the industrial short wood sold to this customer was assigned to construction wood.

The MRT is a key parameter for estimates of carbon storage in dead tree biomass and wood products. In this study, the MRT of the wood product classes refers to the mean lifetime of the first products resulting from raw wood processing (primary wood products, Tables 1,2) and assuming an exponential decay (see below) from its finishing to its decomposition or burning. The type, amount, and duration of final use and probable reuse of the products coming from Thuringian forests, are not included in this analysis.

The decay of dead trees in the forest ecosystem is often described by an exponential function (Harmon et al. 1986; Mackensen et al. 2003), but the deterioration and decay process of wood products are highly variable and not well studied. The following three aspects make a life cycle assessment of wood products difficult: (1) the sale of wood products and the time span of their use is strongly dependent on consumer attitudes, socioeconomic constraints, and new trends in furniture and construction styles. Thus, wood products can be replaced by new products before their physical or technological end-of-use is reached, and the same type of product can be used only for a few years or for several decades, (2) The lifespan of some long-living wood products (e.g. wood for construction) and of new wood products (e.g. laminated beams) is largely unknown because the products are still in use, (3) Depending on regional constraints and national laws, wood waste is reused for other products or energy production, or is disposed of to landfill or burned without energy generation.

Many studies considered estimates on decomposition rates in landfills (e.g. Karjalainen et al. 1994; Winjum et al. 1998; Hashimoto et al. 2002; Marland and Marland 2003; Perez-Garcia et al. 2005; Dias et al. 2007). However, a recent case study on decomposition rates in landfills in Australia revealed the uncertainty of currently used 
Table 1 Assignment of sale assortments to wood product classes used for the data on sold timber from the state forest of Thuringia

\begin{tabular}{|c|c|c|c|c|c|c|}
\hline Primary products & $\begin{array}{l}\text { Residuals, } \\
\text { energy } \\
\text { wood }\end{array}$ & $\begin{array}{l}\text { Pulp, poles, packing } \\
\text { material, temporary } \\
\text { constructions }\end{array}$ & $\begin{array}{l}\text { Pallet and pile } \\
\text { wood, ram piles }\end{array}$ & $\begin{array}{l}\text { Furniture, plywood, } \\
\text { wood-based panels }\end{array}$ & $\begin{array}{l}\text { Parquet } \\
\text { wood }\end{array}$ & $\begin{array}{l}\text { Construction } \\
\text { wood, glued } \\
\text { wood }\end{array}$ \\
\hline Product class & 1 & 2 & 3 & 4 & 5 & \\
\hline MRT & 1 year & 3 years & 11 years & 25 years & 43 years & 50 Years \\
\hline Sale assortments/species & \multicolumn{6}{|c|}{ (\% of total sale assortment) } \\
\hline Residues $^{\mathrm{a}}$, all species & 100 & 0 & 0 & 0 & 0 & 0 \\
\hline Energy wood, all species & 100 & 0 & 0 & 0 & 0 & 0 \\
\hline Stacked wood, all species & 100 & 0 & 0 & 0 & 0 & 0 \\
\hline Industrial wood, long, Pinus & 5 & 13 & 0 & 59 & 0 & 23 \\
\hline Industrial wood, long, Picea & 7 & 16 & 0 & 40 & 0 & 37 \\
\hline Industrial wood, long, Quercus & 0 & 0 & 0 & 100 & 0 & 0 \\
\hline Industrial wood, long, Fagus & 0 & 20 & 0 & 80 & 0 & 0 \\
\hline ILHAF $^{\mathrm{b}}$, all species & \multicolumn{6}{|c|}{ Assigned to logs and log segments per species } \\
\hline Industrial wood, short, Pinus & 50 & 0 & 0 & 50 & 0 & 0 \\
\hline Industrial wood, short, Picea & 95 & 0 & 0 & 5 & 0 & 0 \\
\hline $\begin{array}{l}\text { Industrial wood, short, Quercus } \\
\text { and Fagus }\end{array}$ & 100 & 0 & 0 & 0 & 0 & 0 \\
\hline $\begin{array}{l}\text { Logs, log segments, ILHAF, } \\
\text { parquet wood, pallet wood, } \\
\text { Pinus }\end{array}$ & 9 & 27 & 0 & 18 & 0 & 46 \\
\hline $\begin{array}{l}\text { Logs, log segments, ILHAF, pallet } \\
\text { wood, Picea }\end{array}$ & 9 & 45 & 0 & 0 & 0 & 46 \\
\hline $\begin{array}{l}\text { Logs, log segments, pallet wood, } \\
\text { sleepers, Quercus }\end{array}$ & 4 & 0 & 20 & 76 & 0 & 0 \\
\hline Parquet wood, Quercus & 60 & 0 & 0 & 15 & 25 & 0 \\
\hline $\begin{array}{l}\text { Logs, log segments, pallet wood, } \\
\text { sleepers, Fagus }\end{array}$ & 4 & 17 & 4 & 75 & 0 & 0 \\
\hline Parquet wood, Fagus & 60 & 5 & 0 & 10 & 25 & 0 \\
\hline Poles, ram piles, all species & 0 & 0 & 100 & 0 & 0 & 0 \\
\hline Small poles, pile wood, all species & 0 & 100 & 0 & 0 & 0 & 0 \\
\hline
\end{tabular}

Logs $=$ round timber $=$ sawn timber

${ }^{a}$ Residues: felled wood, DBH $>7 \mathrm{~cm}$, that remains in the forest or is collected by local people for firewood. This type of timber is an extra category that is not included in sale assortments regularly (German technical term: x- and nvD-wood)

b ILHAF denotes Industrial wood, long, that was sold as sawn timber to the German Timber Promotion Fund, all species

${ }^{c}$ Wood-based panels including particle board, fibreboard, and wood plastic composites

estimates (Ximenes et al. 2008). To our knowledge, there is no comprehensive study providing real data on decomposition rates in landfills, and the proportion of wood products that is recycled or used for energy production in Europe. Taking into account, this lack of data and recent changes in the regulation of wood waste in Germany, which prohibits wood disposal to landfill, we used a simple exponential decay model (first-order decay model) also for wood products (Eq. 1) and excluded a potential secondary use or long residence times in landfills.

$y_{t}=y_{0} \cdot \mathrm{e}^{-k t}$,

with $y_{t}$ denotes quantity of wood left at time $t, y_{0}$ initial quantity of wood, $k$ decay rate constant, and $t$ time.
Assuming an exponential decay, the MRT is the time that goes by until $63 \%$ of the initial amount of a wood product is decomposed or burned (Eq. 2).

MRT $=\frac{1}{k} \approx-\frac{\ln (0.37)}{k}$,

with MRT denotes mean residence time (years).

Conversion to carbon equivalents

Wood volume of the four tree species groups was converted to biomass by Eq. 3 .

$C_{\mathrm{M}}=\frac{V \cdot D}{1,000} \cdot C_{\text {conc. }}$, 
Table 2 Overview of the assignment of timber assortments to wood product classes $(\mathrm{PC})$ used for the thinning scenarios

\begin{tabular}{lllllll}
\hline Species & PC & 1 & 2 & 3 & 4 & 6 \\
& MRT & 1 Year & 3 Years & 11 Years & 25 Years & 50 Years \\
& DBH $(\mathrm{cm})$ & & & $(\%)$ & &
\end{tabular}

\begin{tabular}{|c|c|c|c|c|c|c|}
\hline \multirow[t]{14}{*}{ Spruce } & 11 & 24 & 62 & 0 & 3 & 11 \\
\hline & 12 & 22 & 60 & 0 & 2 & 16 \\
\hline & 13 & 20 & 58 & 0 & 2 & 20 \\
\hline & 14 & 19 & 55 & 0 & 2 & 25 \\
\hline & 15 & 17 & 53 & 0 & 1 & 28 \\
\hline & 16 & 17 & 51 & 0 & 1 & 31 \\
\hline & 17 & 16 & 50 & 0 & 1 & 34 \\
\hline & 18 & 15 & 48 & 0 & 1 & 36 \\
\hline & 19 & 15 & 47 & 0 & 1 & 38 \\
\hline & 20 & 15 & 46 & 0 & 0 & 39 \\
\hline & $21-22$ & 16 & 44 & 0 & 0 & 40 \\
\hline & $23-32$ & 15 & 43 & 0 & 0 & 42 \\
\hline & 33 & 14 & 43 & 0 & 0 & 43 \\
\hline & $34-60$ & 13 & 43 & 0 & 0 & 44 \\
\hline \multirow[t]{22}{*}{ Pine } & $12-13$ & 8 & 34 & 0 & 50 & 8 \\
\hline & 14 & 12 & 29 & 0 & 49 & 11 \\
\hline & 15 & 14 & 25 & 0 & 48 & 14 \\
\hline & 16 & 14 & 23 & 0 & 47 & 16 \\
\hline & 17 & 14 & 21 & 0 & 47 & 18 \\
\hline & 18 & 14 & 20 & 0 & 46 & 20 \\
\hline & 19 & 14 & 20 & 0 & 45 & 21 \\
\hline & 20 & 14 & 20 & 0 & 43 & 24 \\
\hline & 21 & 14 & 20 & 0 & 41 & 26 \\
\hline & 22 & 13 & 20 & 0 & 39 & 28 \\
\hline & 23 & 14 & 21 & 0 & 36 & 29 \\
\hline & 24 & 13 & 21 & 0 & 34 & 31 \\
\hline & 25 & 13 & 22 & 0 & 31 & 33 \\
\hline & 26 & 13 & 23 & 0 & 29 & 36 \\
\hline & 27 & 13 & 23 & 0 & 27 & 37 \\
\hline & 28 & 13 & 24 & 0 & 25 & 38 \\
\hline & 29 & 13 & 24 & 0 & 24 & 39 \\
\hline & $30-31$ & 13 & 24 & 0 & 23 & 40 \\
\hline & $32-33$ & 13 & 25 & 0 & 21 & 41 \\
\hline & $34-35$ & 12 & 25 & 0 & 21 & 42 \\
\hline & $36-47$ & 12 & 25 & 0 & 20 & 43 \\
\hline & $48-60$ & 11 & 26 & 0 & 19 & 44 \\
\hline
\end{tabular}

For spruce timber with a DBH below $25 \mathrm{~cm}$ the assortments tables of Schöpfer and Stöhr (1991) were used, for all other cases the tables of Schöpfer and Dauber (1985). Product class 5 is not listed in the timber assortments; wood that would fit into this class is integrated in class 6

with $C_{\mathrm{M}}$ denotes carbon stock (t C), $V$ timber volume $\left(\mathrm{m}^{3}\right)$, $D$ species-specific basic wood density $\left(\mathrm{kg} \mathrm{m}^{-3}\right), C_{\text {conc }}$ carbon concentration $\left(0.504 \mathrm{~g} \mathrm{C} \mathrm{g} \mathrm{g}_{\text {dry wood }}^{-1}\right.$ ).

If recently cut timber is the input variable for the chain of wood from the cut tree to the saw mill, and finally the wood products, as in our study, the basic wood density (=absolute dry weight of wood/fresh volume of wood) is needed to convert timber volume into wood biomass. The basic wood density is about $10-20 \%$ lower than other measures of wood density that express the absolute dry weight of wood compared with wood volume at lower water contents. They are used, for example, in tree ring analyses or wood technology. For most tree species, the basic wood density varies by tree ring width, and consequently, by site and weather conditions, so that for regional studies also regional data should be used. In our study, we used species-specific basic wood densities as given by Burschel et al. (1993) in a study on the carbon balance of German forests. These values represent mean values for Germany and Thuringia as shown by many case studies and regional forestry handbooks [e.g. Picea abies: Kahl 2003 (Thuringian forest), Mund et al. 2002 (northern Bavaria), J. Schuhmacher and C. Wirth, unpublished (Thuringian forest); F. sylvatica: M. Mund, unpublished (western Thuringia), Pistorius 2007 (Baden-Wuerttemberg); handbooks: Mette and Korell 1989; Kollmann 1982]. The used basic wood densities are $554 \mathrm{~kg} \mathrm{~m}^{-3}$ for beech, $561 \mathrm{~kg} \mathrm{~m}^{-3}$ for oak, $377 \mathrm{~kg} \mathrm{~m}^{-3}$ for spruce, and $431 \mathrm{~kg} \mathrm{~m}^{-3}$ for pine. The amount of carbon was calculated assuming a carbon concentration of woody biomass of $50.4 \%$ (Wirth et al. 2004). Error estimates of these parameters are given in Sect. "Methodological considerations and data quality" below.

Thinning scenarios for coniferous stands of the Thuringian forest district "Hummelshain"

To analyse the impact of different thinning regimes on the basis of an existing forested area and with commonly available data, we used the forest management plan (19992009) for the forest district "Hummelshain", eastern Thuringia, as a primary data source. Data like this should be available for all intensively managed forests in Europe, so that our approach could be transferred to other regions.

The forest district "Hummelshain" has been managed according to silvicultural standards in Thuringia, and its ecosystem carbon stocks and changes were already investigated by Wirth et al. (2004). About $84 \%$ of the district area is characterised by soils of medium to poor nutrient availability on Triassic sandstone (Brown soils and Podsols). The remaining 16\% are nutrient rich soils on Triassic limestone (Rendzina or Brown soil-Rendzina). Elevation ranges between 160 and 440 masl, mean annual precipitation is 550-650 mm, and mean annual air temperature $7.5^{\circ} \mathrm{C}$.

According to the recent forest management plan (1999), the state forested area comprises 4,163 ha. The average growing stock is $276 \mathrm{~m}^{3} \mathrm{ha}^{-1}$ and the annual increment $9.7 \mathrm{~m}^{3} \mathrm{ha}^{-1}$. The forest district is dominated by even-aged, 
mono-species stands of pine and spruce. The age-class distribution is characterised by a clear surplus of stands between 41 and 60 years affecting stand volume distribution and timber production (Fig. 1). The surplus of middleaged stands is typical for public forests in Thuringia and Germany (BMVEL 2004b), and it will affect the total amount of future timber yield (Vetter et al. 2005) and the diameter distribution of harvested timber that in turn influences the suitability for long-lived wood products (see above).

In the thinning scenarios, we compared the lifetime of wood products processed from spruce and pine timber assortments that would be the outcome of two common thinning methods: (A) thinning from below (=low thinning), and (B) thinning from above (=crown thinning). Based on Röhrig et al. (2006), Burschel and Huss (2003), and Nyland (1996), we defined the thinning regimes as follows: (A) thinning from below is the removal of less competitive overtopped trees, and, depending on the thinning intensity (thinning degree), also of intermediate, and some codominant trees. This thinning strategy removes gradually the lower and intermediate canopy evenly distributed over the area and results in a stand with uniform tree heights and stem diameters. (B) Thinning from above is the removal of dominant and codominant trees, and thus reduces crowding within the main canopy. The objectives of thinning from above are (1) establishing and maintaining a vertical stand structure by leaving the intermediate and lower canopy, and (2) to stimulate the stem growth of remaining trees with good crown and wood qualities. As a result of thinning from below, the mean DBH of the timber removed is smaller than the mean $\mathrm{DBH}$ of the remaining

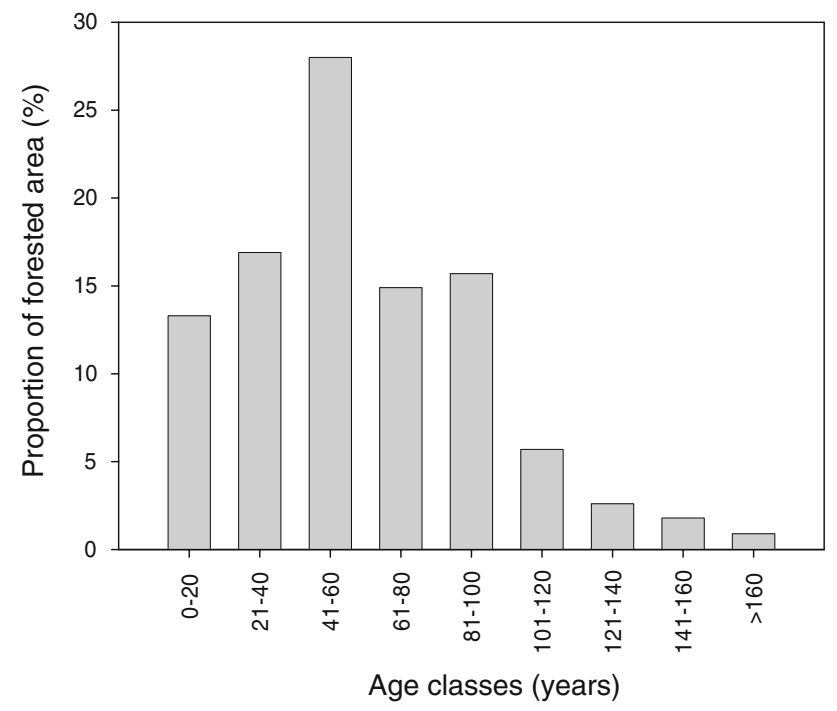

Fig. 1 Age-class distribution (all tree species) in public forests of the forest district "Hummelshain" as given in the forest management plan for 1999-2009 stand. After thinning from above, the mean stand DBH decreases compared with thinning from below, and the mean DBH of the harvested trees is higher than the mean DBH of the stand before thinning. The mean DBH of the final mature stand is higher than after a thinning regime from below. Briefly, it may be summarised as thinning from below aims at a high mass production per hectare, thinning from above aims at high-value mass per tree.

Thinning regimes, their practical implication and modification in the field vary amongst tree species, age classes, site and stand conditions, and the main production target. Therefore, in this study, we compared the most strictly defined and most contrasting thinning regimes "thinning from above" and "thinning from below" carried out over an entire rotation in coniferous stands. With this specification, we suppose that the scenarios represent the maximum differences in carbon stocks and lifetimes of wood products that can be reached by different thinning methods. However, it has to be mentioned that thinning from below throughout the entire rotation period is not recommended in spruce management, at least in Germany. In the past, Thuringia belonged to former Eastern Germany where silviculture focused on a maximisation of stem volume and increment per hectare and on stand stability rather than on single tree stability (Barth 1988). Thinning from below was recommended especially for spruce (Wenk et al. 1990; Thomasius et al. 1986). Regional yield tables used as the main source for planning in Thuringia indicated this strategy and assumed a graded low thinning regime for spruce and pine (yield tables: Wenk et al. 1985; Lembcke et al. 1975). Today, silvicultural concepts of Thuringia's state forestry and permanent silviculture training courses for foresters promote thinning from above. Thus, a transition from thinning from below to above is typical for evenaged coniferous forests in Thuringia, and can be assumed as nearly completed in public forests of many European countries. In other parts of the world, where even-aged management associated with clearcut harvesting prevails, thinning from below remains to be a common practice in coniferous stands. In forestry praxis, private forest ownerships, and forest economy, the advantages and disadvantages of thinning from below in coniferous stands are still under discussion; for example, with respect to interest rates (Knoke 1998; Beinhofer 2008), wood quality (Pfister et al. 2007), or adaptation strategies of the forestry sector to climate change (Wagner 2008; Rigling et al. 2008). At present, it is not clear whether new wood technology (e.g. profiling technology for softwood in combination with technologies for producing laminated wood beams and finger jointing), and an increasing mechanization of thinning and harvesting in coniferous forests will promote homogenous, even-sized small timber thinned exclusively from below. 
For both thinning scenarios, the same total yield per stand within the planning period was assumed, because no data on differences between the two thinning regimes in the study region are available. In the forest management plan, the basal area of the stands and the planned total yield is specified for the main tree species groups mentioned above. In contrast to the timber sale analysis that was based on sale assortments, a direct assignment of total planned yield data to wood products is not possible because of the lack of quality information on future yield. Thus, the planned total yield per stand was allocated to timber assortment classes that are based on the species-specific diameter distributions of harvested trees, and then to the product classes. For spruce timber with a DBH below $25 \mathrm{~cm}$, the timber assortment tables of Schöpfer and Stöhr (1991) were applied, and for all other cases the tables of Schöpfer and Dauber (1985) were applied.

For the thinning from below scenario, mean DBH per thinning operation was taken from yield tables used in Thuringia (yield table collection for Thuringia, FHS 1997, spruce: Wenk et al. 1985; pine: Lembcke et al. 1975). These tables were developed in the second half of the twentieth century, and represent a stand model and management plan that uses a graded thinning from below regime to get homogeneous, even-aged stands. For a thinning regime from above, the Thuringian State Institute for Forestry, Game and Fishery (Department of Forest Inventories and Planning, TLWJF 2003) developed a catalogue of target diameters for all groups of tree species and diameter classes per thinning operation. Thinning operations in the lower and intermediate canopy were not considered because usually they are cut and left on site in precommercial operations. Timber yield of final harvests (clear cuttings) was processed similar to that of thinning operations in old forests. This generalisation was reasonable, because of the low proportion of old stands (Fig. 1) and thus, final cuttings at the forest district "Hummelshain" during the planning period (1999-2009), and because of the small differences between the sale assortments resulting from the last thinning operation and the final cutting.

Methodological considerations and data quality

The quality of our calculations and scenarios of forest wood products differs depending on the data sources available. The calculations of previously sold timber from Thuringia state forests and resulting wood products were done on the basis of the real timber harvest and sale assortments as documented in the database. These data are only biased by measurement errors, which in practice are usually assumed to be $<10 \%$. The relative error of the basic wood density for beech and spruce used in this study (see above) amounts to 8 and $12 \%$, respectively (Wirth et al. 2004). The carbon concentration of wood is with an error of $1 \%$ (Wirth et al. 2004) only a minor source of uncertainty.

To obtain at least rough estimates on timber processing, product yield, and the utilisation of residues in Thuringia, a mail and telephone enquiry of the most important wood customers was conducted. However, the information from sawmills, wood manufacturers, and timber-trading companies involved in this study may be biased by personal opinions and incomplete statements for competitive reasons, and thus, should be regarded as a general data rather than completely verified information that influenced the assignment of the sale or timber assortments to the product classes. A quantification of these uncertainties is obviously not possible. In questionable cases, the product class with a shorter MRT was chosen to avoid an overestimation of carbon sequestration in wood products.

In contrast to the calculations for the harvested wood products from Thuringian state forests, the thinning scenarios had to be based on the timber assortment tables. These tables include fewer product classes than the sale assortments, and do not reflect timber quality. Furthermore, the latest, available timber assortment tables were developed in the 1980s and early 1990s. Recent changes in sawmill technologies and in assortment classifications have led to differences in sale assortments and customer structure. New sale assortments have emerged, e.g. log segments, while other assortments have disappeared.

The recent development of profiling technology for softwood has changed the whole softwood market. This technology allows the cost-effective production of sawn timber from log segments that were left in the forest or sold for low-value products in the past. For example, log segments that were often processed for glued wood and then used for construction wood, are considered, as far as possible, in the timber assortments tables for spruce (Schöpfer and Stöhr 1991), but not for pine (Schöpfer and Dauber 1985). Thus, the scenarios for different management strategies are assumed to represent carbon stocks in wood products and their MRT under the constraints of the wood processing technology for the last 5-10 years.

\section{Results}

Assignment of sale and timber assortments to product classes and mean residence times

It was possible to transfer the timber sale data given in the forestry database to wood product classes and their average MRTs based on (1) the product classification scheme by Wirth et al. (2004), (2) an enquiry of the most important 
companies of Thuringia's wood industry, and (3) on expert estimates where information was missing. Tables 1 and 2 summarise the assignment of all designed sale and timber assortments and species groups to the product classes.

Figure 2 illustrates the entire procedure of data processing in this study for beech and spruce, starting from the diameter and quality of harvested timber, and its classification to sale assortments (step 1) followed by the quantification of the really sold timber per sale assortment (step 2 ), and ending at the final product classes (step 3). The first step indicates the high influence of timber quality on the wood sales market, and steps 2 and 3 show the high influence of new wood processing technologies, and the main production lines of the customers. These qualitative factors of steps 1-3 are generally ignored when modelling harvested wood products on the basis of timber dimensions only and generalised production lines.

As mentioned in the method section, the development of profiling technology for softwood has changed the whole softwood market. This technology allows the cost-effective production of sawn timber from log segments that were left in the forest or sold for low value in the past under the anticipation of the producer that these logs serve only for low-value products. Because of the high wood density, the profiling technology is not yet used for hardwood timber. However, in the hardwood sector, the relatively new assortment "parquet wood" has completely changed the assortment structure. Now, tree segments with a middiameter of about $25 \mathrm{~cm}$ and medium quality can be sold as parquet wood (Fig. 2). This wood was traditionally left in

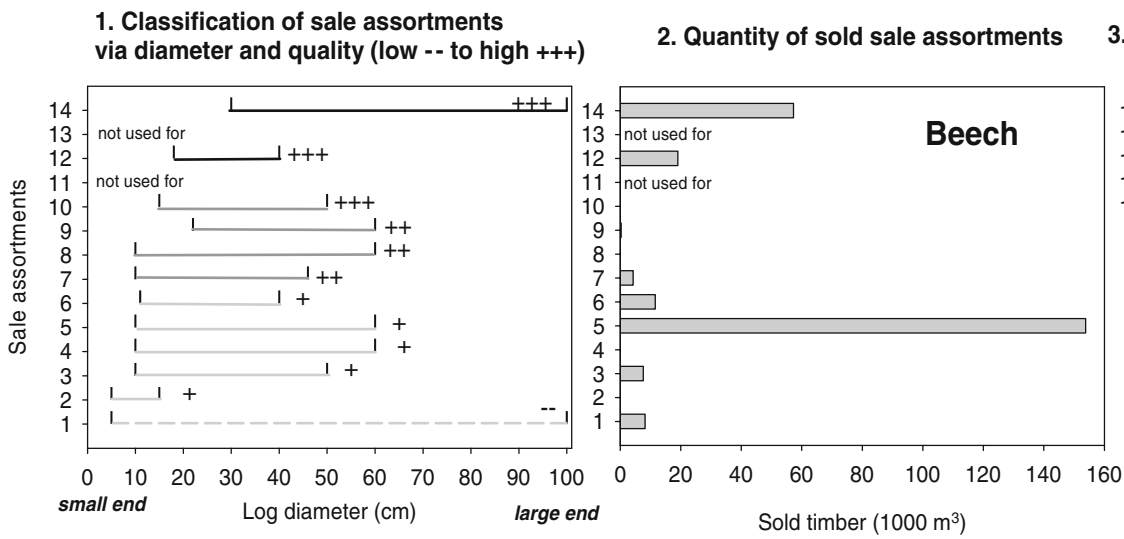

3. Transition of sale assortments to product classes
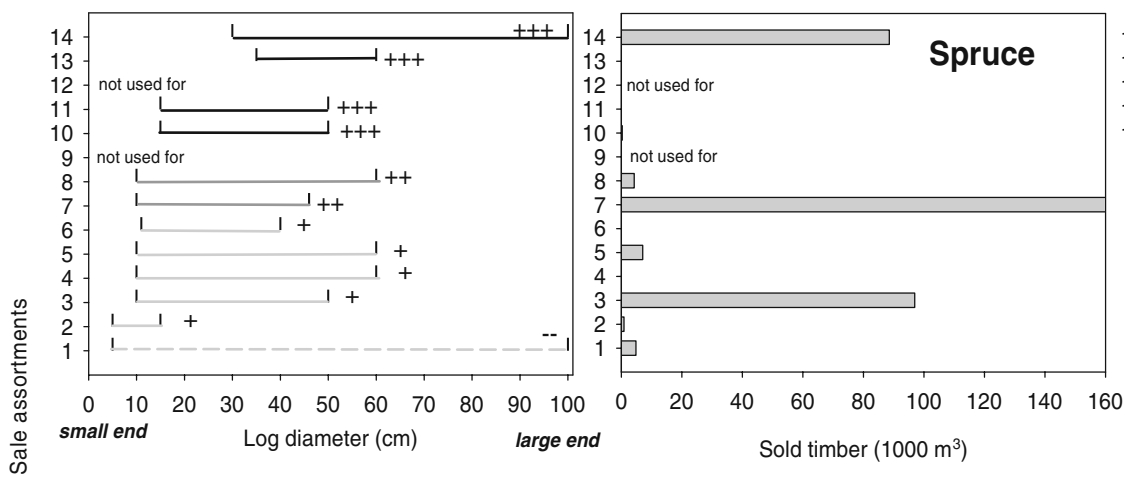
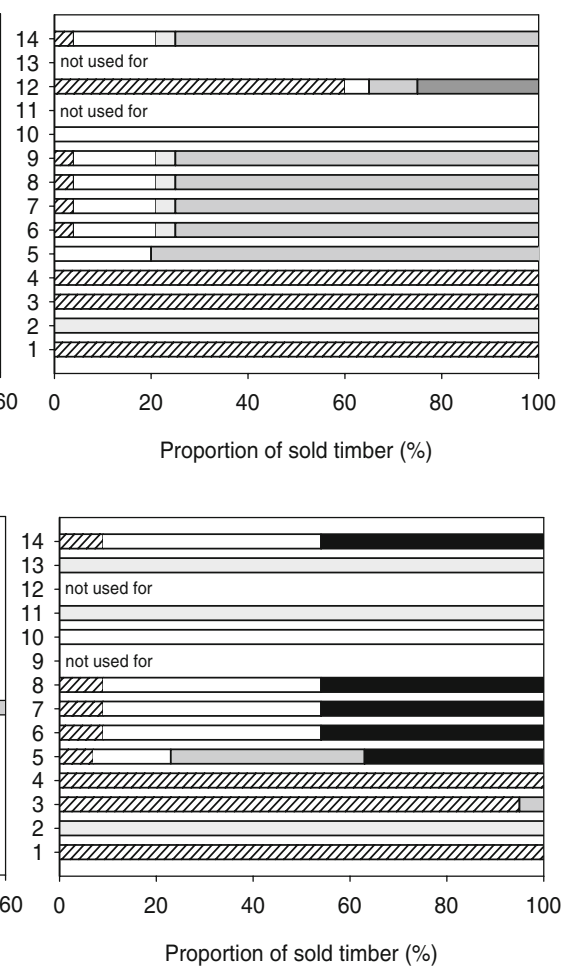

\begin{tabular}{|ll|}
\hline Sale assortments & \\
1:Energy wood & 8:ILHAF \\
2:Small poles & 9:Sleepers \\
3:Industrial wood, short & 10:Pile wood \\
4:Stacked wood & $11:$ Poles \\
5:Industrial wood, long & $12:$ Parquet wood \\
6:Pallet wood & $13:$ Ram piles \\
7:Log segments & $14:$ Logs \\
\hline
\end{tabular}

Fig. 2 Scheme of data processing for beech (above) and spruce (below), starting with the sale assortments classified via diameter and quality of harvested timber (step 1), followed by the quantification of sold timber from Thuringian state forests (step 2, forestry database
ZIIIS PC 1: residuals, energy wood

PC 2: pulp, poles, packing materials, temporary constructions PC 3: pallet and pile wood, ram piles

PC 4: furniture, plywood, wood-based panels

PC 5: parquet wood

PC 6: construction wood, glued wood

ABIES-FIS), and finally the assignment to product classes (step 3). ILHAF denotes Industrial wood, long, that was sold as sawn timber to the German Timber Promotion Fund 
the forest or sold as fuel wood and, therefore, was assigned to product group 1 with a short lifetime. Also industrial wood long, sold to the German Timber Promotion Fund (assortment: ILHAF), is being partly used for glued wood (spruce) or wood-based panels and parquet wood (beech), which are new products that have a higher lifetime than would be expected from the category industrial wood.

Carbon stocks and mean residence time in harvested wood products

Total annual timber sale from Thuringian state forests increased from about $136,893 \mathrm{tC}$ (equivalent to $620,107 \mathrm{~m}^{3}$ or $0.7 \mathrm{t} \mathrm{C} \mathrm{ha}^{-1}$ year $^{-1}$ ) in 1996 to $280,194 \mathrm{t} \mathrm{C}$ $\left(\sim 1,269,235 \mathrm{~m}^{3}\right.$ or $1.4 \mathrm{t} \mathrm{C} \mathrm{ha}^{-1}$ year $^{-1}$ ) in 2005 (forestry database ABIES-FIS). The timber sale in 2001 and 2002, the years that were analysed in detail, resulted in a mean carbon input to the wood product sector of about 206,729 t C year ${ }^{-1}$ or $1.1 \mathrm{t} \mathrm{C} \mathrm{ha}^{-1}$ year $^{-1}$ (equivalent to $936,445 \mathrm{~m}^{3}$ year $^{-1}$; Table 3). Corresponding to the tree species distribution, most carbon went into products made from spruce $(49 \%)$, followed by the products from beech $(35 \%)$ and pine $(13 \%)$. Oak accounted only for $3 \%$ of the carbon input to the products. Normalised to $1 \mathrm{ha}$, about $1.4 \mathrm{t} \mathrm{C} \mathrm{ha}^{-1}$ year $^{-1}$ of beech timber was added to the wood sector, while $1 \mathrm{t} \mathrm{C} \mathrm{ha}{ }^{-1}$ year $^{-1}$ was contributed by spruce timber. This difference reflects similar annual timber harvest per hectare combined with higher wood density of beech compared with spruce (5.2 compared with $5.0 \mathrm{~m}^{3} \mathrm{ha}^{-1}$ year ${ }^{-1}$, and 554 compared with $377 \mathrm{~kg} \mathrm{~m}^{-3}$ ).

About $47 \%$ of annual total timber harvest went into short-lived wood products with an MRT $<25$ years (Table 4). The proportion of residuals and energy wood (product class 1, MRT 1 year) is about two times higher for hardwood than for softwood. Product class 3 (MRT 11 years, pallet and pile wood, ram piles) comprised by far the smallest amount of wood products (in total $1 \%$ of total harvest) and consisted largely of hardwood. Thirty-one percent of the total harvest went into wood products with an MRT of 25-43 years (mainly furniture, parquet wood, and panel products made from hardwood), and only $22 \%$ was used as construction wood, the product class with the longest MRT (51 years). This product was made solely from conifers. However, softwood was primarily used for short-lived pulpwood (MRT 3 years). This reflects the high demand of the pulpwood industry, but also the fact that the lower end of spruce stems is often affected by wood rot (Heterobasidion annosum). Thus, the high potential of conifers to be used for long-lived construction wood is limited by the high proportion of short-lived pulpwood

Table 3 Annual timber harvest per species group (mean of 2001 and 2002)

\begin{tabular}{|c|c|c|c|c|c|c|c|}
\hline \multirow[t]{2}{*}{ Species } & \multirow[t]{2}{*}{ Forest area (ha) } & \multicolumn{2}{|c|}{ Harvested timber volume } & \multirow[t]{2}{*}{$\begin{array}{l}\text { Proportions } \\
\text { volume }(\%)\end{array}$} & \multicolumn{2}{|c|}{$\begin{array}{l}\text { Carbon equivalent } \\
\text { of harvested timber }\end{array}$} & \multirow[t]{2}{*}{$\begin{array}{l}\text { Proportions } \\
\text { carbon }(\%)\end{array}$} \\
\hline & & $\left(m^{3}\right.$ year $\left.^{-1}\right)$ & $\left(\mathrm{m}^{3} \mathrm{ha}^{-1}\right.$ year $\left.^{-1}\right)$ & & $\left(\mathrm{t} \mathrm{C}\right.$ year $\left.^{-1}\right)$ & $\left(\mathrm{t} \mathrm{C} \mathrm{ha}{ }^{-1}\right.$ year $\left.^{-1}\right)$ & \\
\hline Beech & 50724.1 & 262,265 & 5.2 & 28 & 73,286 & 1.44 & 35 \\
\hline Oak & 7803.7 & 21,686 & 2.8 & 2 & 6,132 & 0.79 & 3 \\
\hline Spruce & 105350.1 & 529,739 & 5.0 & 57 & 100,681 & 0.96 & 49 \\
\hline Pine & 31214.8 & 122,756 & 3.9 & 13 & 26,647 & 0.85 & 13 \\
\hline Total/mean ${ }^{\mathrm{a}}$ & 195092.7 & 936,445 & 4.8 & 100 & 206,729 & 1.06 & 100 \\
\hline
\end{tabular}

The volume includes all aboveground wood biomass above $7 \mathrm{~cm}$ in diameter minus bark biomass and losses due to sawing

${ }^{a}$ Mean of harvested timber normalised to one hectare and weighted by forest area

Table 4 Assignment of harvested timber to product classes (PC) and their mean residence times (MRT)

\begin{tabular}{|c|c|c|c|c|c|c|c|c|}
\hline \multirow[t]{2}{*}{$\begin{array}{l}\text { Species } \\
\text { group }\end{array}$} & \multirow[t]{2}{*}{$\begin{array}{l}\text { Harvested } \\
\text { timber }\end{array}$} & \multicolumn{3}{|c|}{$\begin{array}{l}\text { Short MRT ( } \mathrm{C} \mathrm{ha}^{-1} \text { year }^{-1} \text { ) } \\
\text { (\% per species group) }\end{array}$} & \multicolumn{3}{|c|}{$\begin{array}{l}\text { Long MRT (t C ha }{ }^{-1} \text { year }^{-1} \text { ) } \\
(\% \text { per species group) }\end{array}$} & \multirow[t]{2}{*}{$\begin{array}{l}\text { Weighted MRT } \\
\text { (years) }\end{array}$} \\
\hline & & PC 1 (1 year) & PC 2 (3 years) & PC 3 (11 years) & PC 4 (25 years) & PC 5 (43 years) & PC 6 (50 years) & \\
\hline Beech & $1.44(100)$ & $0.17(12)$ & $0.24(17)$ & $0.01(1)$ & $0.99(69)$ & $0.03(2)$ & $0.00(0)$ & 18.7 \\
\hline Oak & $0.79(100)$ & $0.19(24)$ & $0.01(1)$ & $0.03(4)$ & $0.52(66)$ & $0.04(5)$ & $0.00(0)$ & 19.5 \\
\hline Spruce & $0.96(100)$ & $0.08(8)$ & $0.51(53)$ & $0.00(<1)$ & $0.01(1)$ & $0.00(0)$ & $0.36(37)$ & 20.7 \\
\hline Pine & $0.85(100)$ & $0.07(8)$ & $0.27(31)$ & $0.00(<1)$ & $0.25(29)$ & $0.00(0)$ & $0.27(32)$ & 24.2 \\
\hline Mean & $1.06(100)$ & $0.10(10)$ & $0.38(36)$ & $0.01(<1)$ & $0.33(31)$ & 0.01 & $0.24(22)$ & 20.4 \\
\hline
\end{tabular}

${ }^{\text {a }}$ Weighted by carbon per product class 
resulting in an average MRT of only 23 years. On the other hand, the relatively high carbon density of hardwood and the high proportion of relatively long-lived furniture, plywood, panels, and parquet made of hardwood can only balance the fact that hardwood is rarely used for building houses. The overall MRT of carbon in wood products harvested in Thuringia in 2001 and 2002 was 20 years (=MRT per product class weighted by its total amount).

Effects of the thinning regime on wood products

For the decade 1999-2009, a total yield of 214,956 $\mathrm{m}^{3}$ was planned in the forest enterprise Hummelshain, which is equivalent to an average of about $1.1 \mathrm{t} \mathrm{C} \mathrm{ha}^{-1}$ year $^{-1}$ (Table 5). Pine timber yield accounted for $54 \%$ of total carbon yield followed by spruce with $33 \%$.

The thinning from above scenario resulted in a higher proportion of utilizable wood assortments than thinning from below scenario. This was apparent from the lower fraction of unclassified wood of small dimension that would be the output of thinning from above (Table 6) compared with the thinning from below scenario (Table 6) (0.02 compared with $0.7 \mathrm{t} \mathrm{C} \mathrm{ha}^{-1}$ year ${ }^{-1}$ ). About $54 \%$ of the yield from high thinning compared with about $46 \%$ of the yield from low thinning could be used for product classes with a MRT $\geq 25$ years. On an average thinning from above would lead to carbon stocks in products with short MRTs of $0.51 \mathrm{t} \mathrm{C} \mathrm{ha}^{-1}$ year $^{-1}$ and in products with long MRTs of $0.60 \mathrm{t} \mathrm{C} \mathrm{ha}^{-1} \mathrm{year}^{-1}$. After thinning from below, about $0.60 \mathrm{t} \mathrm{C} \mathrm{ha}^{-1}$ year $^{-1}$ would end up in products with short MRTs, and $0.51 \mathrm{t} \mathrm{C} \mathrm{ha}^{-1}$ year $^{-1}$ in products with long MRTs. The average MRT of all products by thinning from above would be 23 years compared with 18 years resulting from thinning from below. The differences between the thinning scenarios are a direct effect of larger mean DBH of harvested timber from thinning from above.

Table 5 Planned yield for spruce and pine at the forest district "Hummelshain" (planning period 1999-2009; forest management plan 1999)

\begin{tabular}{|c|c|c|c|c|c|}
\hline \multirow[t]{2}{*}{$\begin{array}{l}\text { Species } \\
\text { group }\end{array}$} & \multirow[t]{2}{*}{$\begin{array}{l}\text { Total planned } \\
\text { yield }\left(\mathrm{m}^{3} \text { period }^{-1}\right)\end{array}$} & \multirow[t]{2}{*}{$\begin{array}{l}\text { Planned annual yield } \\
\left(\mathrm{m}^{3} \mathrm{ha}^{-1} \text { year }^{-1}\right)\end{array}$} & \multicolumn{2}{|c|}{$\begin{array}{l}\text { Carbon equivalent } \\
\text { of planned annual yield }\end{array}$} & \multirow[t]{2}{*}{$\begin{array}{l}\text { Proportion } \\
(\%)\end{array}$} \\
\hline & & & t C year ${ }^{-1}$ & t C ha ${ }^{-1}$ year $^{-1}$ & \\
\hline Beech & 17,398 & 4.39 & 4,860 & 1.22 & 11 \\
\hline Oak & 4,087 & 1.69 & 1,156 & 0.48 & 2 \\
\hline Spruce & 80,293 & 6.27 & 15,260 & 1.19 & 33 \\
\hline Pine & 113,178 & 4.79 & 24,568 & 1.04 & 54 \\
\hline Total/mean & 214,956 & 5.1 & 45,844 & 1.10 & 100 \\
\hline
\end{tabular}

Table 6 Thinning from above and thinning from below scenario for spruce and pine stands at the forest district "Hummelshain"

\begin{tabular}{|c|c|c|c|c|c|c|c|c|}
\hline \multirow[t]{2}{*}{ Species group } & \multicolumn{4}{|c|}{ Short MRT ( $\mathrm{t} \mathrm{ha}^{-1}$ year $^{-1}$ ) } & \multicolumn{3}{|c|}{ Long MRT ( $\mathrm{t} \mathrm{C} \mathrm{ha}{ }^{-1}$ year $^{-1}$ ) } & \multirow[t]{2}{*}{ Total } \\
\hline & No class ${ }^{\mathrm{a}}$ & $\begin{array}{l}\text { PC } 1 \\
\text { (1 year) }\end{array}$ & $\begin{array}{l}\text { PC } 2 \\
\text { (3 years) }\end{array}$ & $\begin{array}{l}\text { PC } 3 \\
\text { (11 years) }\end{array}$ & $\begin{array}{l}\text { PC } 4 \\
(25 \text { years })\end{array}$ & $\begin{array}{l}\text { PC } 5 \\
\text { (43 years) }\end{array}$ & $\begin{array}{l}\text { PC } 6 \\
\text { (50 years) }\end{array}$ & \\
\hline \multicolumn{9}{|l|}{ Thinning from above } \\
\hline Spruce & 0.01 & 0.18 & 0.53 & 0 & 0 & n.d. & 0.51 & 1.25 \\
\hline Pine & 0.02 & 0.13 & 0.22 & 0 & 0.31 & n.d. & 0.33 & 1.03 \\
\hline Weighted mean ${ }^{\mathrm{a}}$ & 0.51 & & & & 0.60 & & & 1.11 \\
\hline Proportion $(\%)$ & 46.1 & & & & 53.9 & & & 100 \\
\hline Weighted MRT ${ }^{\mathrm{a}}$ (years) & 1.9 & & & & 48.7 & & & 23.3 \\
\hline \multicolumn{9}{|l|}{ Thinning from below } \\
\hline Spruce & 0.02 & 0.20 & 0.58 & 0 & 0.01 & n.d. & 0.41 & 1.25 \\
\hline Pine & 0.10 & 0.11 & 0.21 & 0 & 0.37 & n.d. & 0.18 & 1.03 \\
\hline Weighted mean ${ }^{\mathrm{b}}$ & 0.60 & & & & 0.51 & & & 1.11 \\
\hline Proportion (\%) & 54.3 & & & & 45.7 & & & 100 \\
\hline Weighted MRT ${ }^{\mathrm{b}}$ (years) & 2.1 & & & & 37.9 & & & 18.4 \\
\hline
\end{tabular}

$P C$ product class, $n . d$. no data: Parquet wood (equivalent to product class 5) is not included in assortment tables

a "No class" (no classification) indicates timber wood that cannot by assigned to an assortment because of its small dimension

b Weighted by mass and forested area per species group and product class 


\section{Discussion}

To our knowledge, this study presents the very first databased approach that allows for the quantification of carbon inputs of a defined forest management unit to the wood product sector. It also presents for the first time a link towards the lifetime of resulting wood product by connecting data on raw timber production, timber sale, wood processing, and product-specific MRTs. Furthermore, our scenarios on various thinning regimes revealed the potential of silvicultural practices to increase the lifetime of wood products.

Carbon storage and lifetime of wood products from Thuringia's forests

Similar to previous estimates in Germany (Burschel et al. 1993), only about $53 \%$ of total timber harvested in Thuringian state forests is processed to wood products with an average lifetime of 25 years and longer. The relatively long-lived products were mainly furniture, parquet wood, and wood-based panels (e.g. fibreboard, particle board) from hardwood and construction wood from softwood. There are many factors influencing this relatively low yield of long-lived products. Initially, a high proportion of softwood and hardwood timber of Thuringian state forests is sold as industrial wood because of its low quality. The main reasons for low quality are former harvesting techniques (e.g. whole tree skidding; $8 \%$ of all trees in Germany are damaged by harvest operations; BMVEL $2004 b)$ and deer damage (17\% of all trees in Thuringia are damaged by deer, TLWJF 2005); both are factors that cause the faster spread of wood-destroying fungi.

Despite the relatively high proportion of spruce timber that was sold to the sawmill industry (about $80 \%$ of total timber harvest), only $40 \%$ was actually processed to longlived products (raw data are not shown in this publication, but given on the internet: http://www.forestandclimate. net/service/profft_et_al.php). The remainder (waste material from wood processing and industrial short wood) was used for pulpwood and energy production. The processing of beech timber is dominated by the wood-based panel industry that produces fibreboard and particle board. Thus, a high proportion of beech is finally processed to products with a long lifetime, even though it is sold as industrial wood (Tables 1, 2).

The high proportion of oak in products with MRT $\geq 25$ years should be interpreted with care because of its small total volume. Nevertheless, two aspects underline the use of oak timber for long-lived products:

- High proportions of oak timber even those of small dimension ( $\geq 25 \mathrm{~cm}$ central diameter) and medium quality can be sold as parquet wood, a product class with a long lifetime.

- Because of its chemical composition, oak wood cannot be used for pulpwood. Therefore, production residues are mainly used for wood-based panels (fibreboard, particle board, plywood), and only small amounts for energy production.

Considering carbon stocks in wood products and in the forest ecosystem, timber use would result in higher total carbon stocks of the entire forestry sector only when the MRT in living trees and wood products is higher than the MRT in living trees and dead wood. A comparison of the MRTs of wood products from Thuringian forests with MRTs estimated for dead wood indicates a slight advantage of carbon storage in forest ecosystems compared with wood products (Table 7). However, as the thinning scenarios have shown there is still the potential of increasing the proportion of long-lived wood products and thus, the mean storage of carbon in wood products. Furthermore, considering substitution effects and wood recycling, that were not included in this study, the $\mathrm{CO}_{2}$-mitigation potential of carbon-orientated forest use may exceed that of unused forests under favourable site conditions (Freibauer et al., submitted).

As mentioned in Sect. "Methodological considerations and data quality", a number of assumptions had to be made in this study. However, the data on sold timber and its sale assortments in combination with information on wood buyers allowed for a sound regional and data-orientated quantification of carbon stocks and lifetimes of wood products. To obtain a second, independent estimate, we recalculated our data using the products module of the "CO2FIX" model (version 2.0, Nabuurs et al. 2001; Table 8). The user-friendly, widespread and acknowledged forest carbon model CO2FIX is mainly designed for calculations at stand level, but in the adjacent products module it also provides default values for carbon analyses

Table 7 Average mean residence time (MRT), and average total residence time of wood products from timber harvested in Thuringian state forests (this study) and of dead wood in temperate forest ecosystems (Wirth et al. 2004)

\begin{tabular}{lll}
\hline Species group & \multicolumn{2}{l}{ MRT (total residence time) (years) } \\
\cline { 2 - 3 } & Wood products & Dead wood \\
\hline Beech & $19(56)$ & Deciduous trees, $14(41)$ \\
Oak & $20(59)$ & \\
Spruce & $21(62)$ & Coniferous trees, $34(103)$ \\
Pine & $24(73)$ & \\
Mean Thuringia $^{a}$ & $20(62)$ & $28(84)$
\end{tabular}

${ }^{\text {a }}$ Weighted by area. MRT $=\mathrm{t} 63=63 \%$ of the initial amount of a wood product is decomposed or burned, total residence time $=\mathrm{t} 95=95 \%$ of the initial amount of a wood product is decomposed or burned 
Table 8 Assignment of harvested timber to product classes (PC) and their mean residence times (MRT, in brackets) using default values of the CO2FIX model (version 2.0, Nabuurs et al. 2001, products module) for timber allocation to product classes

\begin{tabular}{|c|c|c|c|c|c|}
\hline \multirow[t]{2}{*}{$\begin{array}{l}\text { Species } \\
\text { group }\end{array}$} & \multirow{2}{*}{$\begin{array}{l}\text { Products total } \\
\left(\mathrm{t} \mathrm{C} \mathrm{ha} \text { year }^{-1}\right) \\
(\% \text { of species group })\end{array}$} & \multirow{2}{*}{$\begin{array}{l}\text { Short MRT ( } \mathrm{C} \mathrm{ha}^{-1} \text { year }^{-1} \text { ) } \\
\text { (\% of species group) } \\
\text { PC I (1.4 years) }\end{array}$} & \multicolumn{2}{|c|}{$\begin{array}{l}\text { Long MRT ( } \mathrm{C} \mathrm{ha}^{-1} \text { year }^{-1} \text { ) } \\
(\% \text { of species group) }\end{array}$} & \multirow[t]{2}{*}{$\begin{array}{l}\text { Weighted } \\
\text { MRT (years) }\end{array}$} \\
\hline & & & PC II (21.5 years) & $\overline{\text { PC III (43.0 years) }}$ & \\
\hline Beech & $1.44(100)$ & $1.09(75)$ & $0.21(15)$ & $0.15(10)$ & 8.6 \\
\hline Oak & $0.79(100)$ & $0.58(74)$ & $0.11(15)$ & $0.09(11)$ & 9.1 \\
\hline Spruce & $0.96(100)$ & $0.61(64)$ & $0.17(18)$ & $0.17(18)$ & 12.5 \\
\hline Pine & $0.85(100)$ & $0.58(68)$ & $0.14(17)$ & $0.13(15)$ & 11.1 \\
\hline Total & $1.06(100)$ & $0.73(69)$ & $0.18(16)$ & $0.15(15)$ & 10.8 \\
\hline
\end{tabular}

Table 9 Proportions of short-lived and long-lived products resulting from the methodology used in this study and from calculations with the CO2FIX model, exemplified for comparable assortments that were taken as primary quality information

\begin{tabular}{|c|c|c|c|c|}
\hline Species group & Assortments & & $\begin{array}{l}\text { Short-lived products, } \\
\text { MRT }<20 \text { years }(\%)\end{array}$ & $\begin{array}{l}\text { Long-lived products, } \\
\text { MRT }>20 \text { years }(\%)\end{array}$ \\
\hline \multirow[t]{2}{*}{ Beech } & This study: sale assortment & Logs & 24 & 76 \\
\hline & CO2FIX: raw material & Logwood & 78 & 22 \\
\hline \multirow[t]{2}{*}{ Spruce } & This study: sale assortment & Log segments & 53 & 47 \\
\hline & CO2FIX: raw material & Logwood & 78 & 22 \\
\hline
\end{tabular}

of the product sector. For our model calculations, timber sale data from Thuringia were transferred to product classes using default parameters for the production lines, process losses, and lifetime categories of the preset "high processing and recycling efficiency system". The halflifetime of the products (=time that goes by until $50 \%$ of the initial amount of a wood product is decomposed) given in the model was converted to the MRT using Eq. 1. The wood density data were not changed according to the model, because (1) the model defaults were much higher than those common for Thuringia, and (2) changes in other parameters than the allocation scheme may mask the most critical part and main objective of this study: the transition of harvested timber to wood product classes of different lifetimes.

The default values given in the CO2FIX products module led to a substantially higher proportion of products with a short MRT than the estimates of this study [69\% (Table 8) compared with 47\% (Table 4)]. Consequently, also the MRT over all species and product classes was with about 11 years surprisingly low compared with 20 years resulting from sale assortments and associated information on wood buyers in this study. The high estimate of shortlived products applied to all species, but the highest differences between the two approaches occurred for the deciduous species (beech: $75 \%$ short-lived products compared with $30 \%$, oak: $74 \%$ compared with $28 \%$ ).

These discrepancies were caused mainly by the first step of the allocation scheme of the products module. The
CO2FIX products module is a three-step model: (1) fixed proportions of raw material are allocated to different production lines, (2) within each production line a fixed proportion of raw material goes into the category "process losses", and (3) the final products are allocated to different product lifetime classes. In our study, the first step is displaced by the direct transition of sold timber and its sale assortments to primary wood products. Thus, default proportions are displaced by real data on the amount and intended use of sold timber.

The consequences of these differences in primary quality information are exemplified in Table 9 for the quantitatively most important and comparable assortments. The process efficiency of sawnwood assumed by the "high efficiency system" of the CO2FIX products module is lower than specified by the wood processing companies that bought the sawnwood from Thuringia's forests. According to Nabuurs et al. (2001), the products module of the CO2FIX program is based on a model developed for the Finnish forest sector. Thus, we assume that the CO2FIX products module represents a forest management concept that puts more emphasis on pulpwood production than on large-sized timber production, and high-value hardwood timber production and the production of hardwood parquet plays only a minor role. Furthermore, in Thuringia quite a lot of large sawing mills are situated, which may lead to a relatively high production and use of sawnwood, and consequently, to a higher proportion of products with a long lifetime compared with other European regions. 
The thinning scenarios

The thinning scenarios demonstrate the influence of silvicultural strategies on carbon storage in the wood product sector. Thinning from below resulted in a shorter average MRT for all products (18 years) than thinning from above ( 23 years). There is a trend towards slightly lower total timber yields per area due to thinning from above (Nyland 1996; Pape 1999) that was not considered in this study. However, thinning from above is assumed to result in higher tree stability against wind damage (Vanomsen 2006; Freise 2007), and thus, lower carbon losses from the ecosystem after windfall and lower losses of high-value timber. Moreover, thinning from above concentrates the growth almost entirely on trees with high-stem qualities ("future crop trees") that will form the final tree community at the time of stand maturity. Consequently, final tree dimensions are reached faster, and final timber quality is better than after thinning from below (e.g. Nyland 1996; Pape 1999; Hein et al. 2007; Wilhelm et al. 1999) resulting in a better utilisation as high-value wood products with a longer lifespan. It is most likely that a small reduction in total timber yield due to thinning from above would be more balanced with respect to total carbon storage in the forestry sector than thinning from below. Thinning from above is the thinning strategy that should be applied in order to increase carbon storage in wood products and at the same time to maintain a stable biomass stocks in the forest ecosystem.

The observed differences between the two thinning regimes will most likely not become a primary factor for silvicultural decisions. However, multifunctional forestry is characterised by the integration of different objectives with benefits for economy, society, and environment. Substitution effects and improved recycling, that were not the objectives of this study, will add additional benefits of carbon-related forestry as shown by Werner et al. (2006), Hofer et al. (2007), Pistorius (2007), and Profft et al. (2007). In addition, carbon sequestration by the forestry sector will gain increasing importance when prices for carbon storage in the forest ecosystem or for substitution efficiency will rise (Freibauer et al., submitted). Thinning from above in uneven-aged, mixed forests ("target growing stocks" approach) may have the highest potential to combine high ecosystem carbon stocks beyond the length of one rotation period, high biodiversity, and all its specific services and functions, including high amounts of timber production and a large range of timber quality required to react to changes in customer demands (Thomasius 1988; von Gadow and Puumalainen 2000; Schütz 2001).

\section{Conclusions}

The analysis of sale assortments of Thuringian forestry and the management scenarios revealed the role of tree species, timber diameter, and quality for carbon storage in wood products and the potential to increase the proportion of long-lived wood products by thinning from above compared with thinning from below. Owing to the combination of data on the amount and assortments of actually sold timber, and production parameters of the companies that bought and processed the timber, we could consider new wood processing technologies and track the real fate of harvested timber beyond general forest production statistics.

The comparison of our approach based on sold timber, its assortments and information on wood buyers with outcomes from the CO2FIX products module revealed regional differences in forest management concepts and wood processing that result in substantially different lifetimes of the wood products.

The results of this study close the gap between timber harvested in the forest and wood products that were made from this timber, which is essential for a net-carbon balance of the entire forestry sector and for quantification of human-induced changes of carbon stocks according to the Kyoto Protocol. Our approach can be transferred to any other forest management unit where similar data as those of the forest administration database in Thuringia are available.

Acknowledgments This study was supported by financial assistance from the European research cluster CarboEurope and the German Federal Ministry of Education and Research (BMBF, Project OILK9901). We are very grateful to the private companies for cooperation and for providing information on their production processes. We thank Hannes Böttcher for helpful comments on a previous version of the manuscript. The authors are indebted to Neil Turner for editing the English. We thank the unknown reviewers for their helpful comments on a previous version of the manuscript.

Open Access This article is distributed under the terms of the Creative Commons Attribution Noncommercial License which permits any noncommercial use, distribution, and reproduction in any medium, provided the original author(s) and source are credited.

\section{References}

Barth R (1988) Forsteinrichtungspraxis in der Deutschen Demokratischen Republik-Methoden und Verfahren. VEB Forstprojektierung, Potsdam

Becker M, Mellinghoff S (1997) Distribution des Holzes in Deutschland 1995 (Holz-Distributionsanalyse). Holzabsatzfonds, Freiburg

Beinhofer B (2008) Zum optimalen Einschlagszeitpunkt von Fichtenbeständen. Allg Forst Jagdztg 179:121-132 
BMVEL (Bundesministerium für Verbraucherschutz Ernährung und Landwirtschaft) (ed) (2004a) Verstärkte Holznutzung-Zugunsten von Klima, Lebensqualität, Innovationen und Arbeitsplätzen (Charta Holz). BMVEL, Berlin

BMVEL (Bundesministerium für Verbraucherschutz Ernährung und Landwirtschaft) (ed) (2004b) Die Zweite BundeswaldinventurDas Wichtigste in Kürze. Bundesministerium für Verbraucherschutz Ernährung und Landwirtschaft, Berlin

Briceno-Elizondo E, Garcia-Gonzalo J, Peltola H, Kellomaki S (2006) Carbon stocks and timber yield in two boreal forest ecosystems under current and changing climatic conditions subjected to varying management regimes. Environ Sci Policy 9:237-252. doi:10.1016/j.envsci.2005.12.003

Brown S, Lim B, Schlamadinger B (1998) Evaluating approaches for estimating net emissions of carbon dioxide from forest harvesting and wood products. In: IPCC meeting report, May 1998, Dakar, Senegal. International Panel on Climate Change/Organization for Economic and Commercial Development/International Energy Agency Programme on National Greenhouse Gas Inventories, Organization for Economic Cooperation and Development, Paris

Burschel B, Huss J (2003) Grundriss des Waldbaus Ein Leitfaden für Studium und Praxis. Verlag Eugen Ulmer, Stuttgart

Burschel P, Kürsten E, Larson BC (1993) Die Rolle von Wald und Forstwirtschaft im Kohlenstoffhaushalt. Schriftenreihe der Forstwissenschaftlichen Fakultät der Universität München und der Bayerischen Forstlichen Versuchs- und Forschungsanstalt, Freising

Dias AC, Louro M, Arroja L, Capela I (2005) The contribution of wood products to carbon sequestration in Portugal. Ann For Sci 62:903-909. doi:10.1051/forest:2005081

Dias AC, Louro M, Arroja L, Capela I (2007) Carbon estimation in harvested wood products using a country-specific method: Portugal as a case study. Environ Sci Policy 10:250-259. doi: 10.1016/j.envsci.2007.01.002

Eggers T (2002) The impacts of manufacturing and utilisation of wood products on the European carbon budget. Internal Report 9. European Forest Institute, Joensuu

Eriksson E, Gillespie AR, Gustavsson L, Langvall O, Olsson M, Sathre R, Stendahl J (2007) Integrated carbon analysis of forest management practices and wood substitution. Can J For Res 37:671-681. doi:10.1139/X06-257

FHS (Fachhochschule für Forstwirtschaft) (ed) (1997) Ertragstafelauszüge, zusammengestellt von Prof. Dr. Anka Nicke. Fachhochschule für Forstwirtschaft, Schwarzburg

Freibauer A, Böttcher H, Scholz Y, Gitz V, Ciais P, Mund M, Wutzler T, Schulze E-D (submitted) Setting priorities for land management to mitigate climate change. Clim Change

Freise C (2007) Zukunftsorientierte Fichtenwirtschaft. In: Zukunftsorientierte Fichtenwirtschaft-Tagungsband und Projektergebnisse. Thüringer Landesanstalt für Wald, Jagd und Fischerei, Gotha

Green C, Avitabile V, Farrell EP, Byrne KA (2006) Reporting harvested wood products in national greenhouse gas inventories: implications for Ireland. Biomass Bioenergy 30:105-114. doi: 10.1016/j.biombioe.2005.11.001

Gustavsson L, Pingoud K, Sathre R (2006) Carbon dioxide balance of wood substitution: comparing concrete and wood-framed buildings. Mitig Adapt Strateg Glob Change 11:667-691. doi: 10.1007/s11027-006-7207-1

Harmon ME, Franklin JF, Swanson FJ, Sollins P, Gregory SV, Lattin JD, Anderson NH, Cline SP, Aumen NG, Sedell JR, Lienkaemper GW, Cromack KJ, Cummins KW (1986) Ecology of coarse woody debris in temperate ecosystems. Adv Ecol Res 15:133-302. doi:10.1016/S0065-2504(08) 60121-X
Hashimoto S, Nose M, Obara T, Moriguchi Y (2002) Wood products: potential carbon sequestration and impact on net carbon emissions of industrialized countries. Environ Sci Policy 5:183-193. doi:10.1016/S1462-9011(01)00045-4

Hein S, Lenk E, Kladtke J, Kohnle U (2007) Effect of crop tree selective thinning on beech (Fagus sylvatica L.) on wood quality, timber assortment and value production. Allg Forst Jagdztg 178:8-20

Hofer P, Taverna R, Werner F, Kaufmann E, Thürig E (2007) The $\mathrm{CO}_{2}$ effects of the Swiss forestry and timber industry. Federal Office for the Environment, Bern

Kahl T (2003) Abbauraten von Fichtentotholz (Picea abies (L.) Karst.) - Bohrwiderstandsmessungen als neuer Ansatz zur Bestimmung des Totholzabbaus, einer wichtigen Größe im Kohlenstoffhaushalt mitteleuropäischer Wälder. Magisterarbeit, Friedrich-Schiller-Universität Jena

Karjalainen T, Kellomaki S, Pussinen A (1994) Role of wood-based products in absorbing atmospheric carbon. Silva Fenn 28:67-80

Karjalainen T, Pussinen A, Liski J, Nabuurs GJ, Eggers T, Lapvetelainen T, Kaipainen T (2003) Scenario analysis of the impacts of forest management and climate change on the European forest sector carbon budget. For Policy Econ 5:141-155. doi: 10.1016/S1389-9341(03)00021-2

Knoke T (1998) Die Stabilisierung junger Fichtenbestände durch starke Durchforstungseingriffe-Versuch einer ökonomischen Bewertung. Forstarchiv 69:219-226

Kollmann F (1982) Technologie des Holzes und der Holzwerkstoffe, vol 1. Springer, Berlin

Lembcke G, Knapp E, Dittmar O (1975) DDR-Kiefern-Ertragstafel 1975. Eigenverlag Institut für Forstwissenschaften, Eberswalde

Mackensen J, Bauhus J, Webber E (2003) Decomposition rates of coarse woody debris-a review with particular emphasis on Australian tree species. Aust J Bot 51:27-37. doi:10.1071/ BT02014

Marland E, Marland G (2003) The treatment of long-lived, carboncontaining products in inventories of carbon dioxide emissions to the atmosphere. Environ Sci Policy 6:139-152. doi:10.1016/ S1462-9011(03)00003-0

Marland G, Schlamadinger B (1997) Forests for carbon sequestration or fossil fuel substitution-a sensitivity analysis. Biomass Bioenergy 13:389-397. doi:10.1016/S0961-9534(97)00027-5

Mette HJ, Korell U (1989) Richtzahlen und Tabellen für die Forstwirtschaft-Grundlagen der Forstnutzung, Nutzung der Dendromasse, Verwertung von Rohholz, Arbeitskraft, Arbeitsnormung, Arbeitsleistung, Maschinen und Geräte der Rohholzerzeugung und Rohholzbereitstellung, Forstwegebau, Internationale Standardisierung, Maßsystem, Einheiten. VEB Deutscher Landwirtschaftsverlag, Berlin

Mund M, Kummetz E, Hein M, Bauer GA, Schulze E-D (2002) Growth and carbon stocks of a spruce forest chronosequence in central Europe. For Ecol Manage 171:275-296. doi: 10.1016/S0378-1127(01)00788-5

Nabuurs GJ, Sikkema R (2001) International trade in wood products: its role in the land use change and forestry carbon cycle. Clim Change 49:377-395. doi:10.1023/A:1010732726540

Nabuurs GJ, Garza-Caligaris JF, Kanninen M, Karjalainen T, Lapvetelainen T, Liski J, Masera O, Mohren GMJ, Pussinen A, Schelhaas MJ (2001) CO2FIX V2.0-manual of a model for quantifying carbon sequestration in forest ecosystems and wood products. ALTERRA Report 445, Wageningen

Nabuurs GJ, Masera O, Andrasko K, Benitez-Ponce P, Boer R, Dutschke M, Elsiddig E, Ford-Robertson J, Frumhoff $P$, Karjalainen T, Krankina O, Kurz WA, Matsumoto M, Oyhantcabal W, Ravindranath NH, Sanz Sanchez MJ, Zhang X (2007) Forestry. In: Metz B, Davidson OR, Bosch PR, Dave R, Meyer LA (eds) Climate change 2007: mitigation. Contribution of 
Working Group III to the Fourth Assessment Report of the Intergovernmental Panel on Climate Change. Cambridge University Press, Cambridge

Nyland RD (1996) Silviculture: concepts and applications. Mc GrawHill, Boston

Pape R (1999) Effects of thinning regime on the wood properties and stem quality of Picea abies. Scand J For Res 14:38-50

Perez-Garcia J, Lippke B, Comnick J, Manriquez C (2005) An assessment of carbon pools, storage, and wood products market substitution using life-cycle analysis results. Wood Fiber Sci 37:140-148

Petersen AK, Solberg B (2005) Environmental and economic impacts of substitution between wood products and alternative materials: a review of micro-level analyses from Norway and Sweden. For Policy Econ 7:249-259. doi:10.1016/S1389-9341(03)00063-7

Pfister O, Wallentin C, Nilsson U, Eko PM (2007) Effects of wide spacing and thinning strategies on wood quality in Norway spruce (Picea abies) stands in southern Sweden. Scand J For Res 22:333-343. doi:10.1080/02827580701504951

Pingoud K, Wagner F (2006) Methane emissions from landfills and carbon dynamics of harvested wood products: the first-order decay revisited. Mitig Adapt Strateg Glob Change 11:961-978. doi:10.1007/s11027-006-9029-6

Pistorius T (2007) Untersuchungen zur Rolle des Waldes und der Forstwirtschaft im Kohlenstoffhaushalt des Landes BadenWürttemberg. Berichte Freiburger Forstliche Forschung, Heft 73. FVA, Baden-Württemberg

Profft I, Seiler M, Arenhövel W (2007) Wald \& Holz-Potential für den Klimaschutz in Thüringen. In: Klimaschutz und Klimawandel-Rolle der Forstwirtschaft (conference proceedings). Thüringer Landesanstalt für Wald, Jagd und Fischerei, Gotha, pp 42 56

Rigling A, Brang $\mathrm{P}$, Bugmann $\mathrm{H}$, Kräuchi $\mathrm{N}$, Wohlgemuth $\mathrm{T}$, Zimmermann N (2008) Klimawandel als Prüfstein für die Waldbewirtschaftung. Schweiz Z Forstwesen 159:316-325

Röhrig E, Bartsch N, von Lüpke B (originally: Dengler, A.) (2006) Waldbau auf ökologischer Grundlage, 7th edn. Verlag Eugen Ulmer, Stuttgart

Schöpfer W, Dauber E (1985) Bestandessortentafeln 1982/85. In: Forst-, Holz- und Jagd-Taschenbuch 1986. M. u. H. Schaper, Hannover

Schöpfer W, Stöhr D (1991) Variable Bestandessortentafeln für Fichten-Schwachholzhiebe. Mitteilungen der FVA Baden-Württemberg, Heft 162. FVA, Baden-Württemberg

Schütz J-P (2001) Der Plenterwald und weitere Formen strukturierter und gemischter Wälder. Parey, Berlin

Seidl R, Rammer W, Jäger D, Currie WS, Lexer MJ (2007) Assessing trade-offs between carbon sequestration and timber production within a framework of multi-purpose forestry in Austria. For Ecol Manage 248:64-79. doi:10.1016/j.foreco.2007.02.035

Thomasius H (1988) Stabilität natürlicher und künstlicher Waldökosysteme sowie deren Beeinflußbarkeit durch forstwirtschaftliche Maßnahmen. Allg Forstzeitung 43:1037-1043
Thomasius H, Butter D, Marsch M (1986) Maßnahmen zur Stabilisierung von Fichtenforsten gegenüber Schnee- und Sturmschäden. Beitrag zum 18. Welt-Kongress der IUFRO, Dresden

TLWJF (Thüringer Landesanstalt für Wald Jagd und Fischerei) (ed) (2003) Hilfstafeln zur naturalen Betriebssteuerung. TLWJF, Gotha

TLWJF (Thüringer Landesanstalt für Wald Jagd und Fischerei) (ed) (2005) Bundeswaldinventur II im Freistaat Thüringen. Mitteilungen, Heft 24/2005, Gotha

TMLNU (Thüringer Ministerium für Landwirtschaft Naturschutz und Umwelt) (ed) (2006) Forstbericht 2006. TMLNU, Erfurt

Vanomsen P (2006) Der Einfluss der Durchforstung auf die Verankerung der Fichte hinsichtlich ihrer Sturmresistenz. Dissertation, Eidgenössische Technische Hochschule Zürich

von Gadow K, Puumalainen J (2000) Scenario planning for sustainable forest management. In: von Gadow K, Pukkala T, Tomé M (eds) Sustainable forest management. Kluwer Academic Publishers Group, Dordrecht, pp 319-356

Vetter M, Wirth C, Böttcher H, Churkina G, Schulze ED, Wutzler T, Weber G (2005) Partitioning direct and indirect human-induced effects on carbon sequestration of managed coniferous forests using model simulations and forest inventories. Glob Change Biol 11:810-827. doi:10.1111/j.1365-2486.2005.00932.x

Wagner S (2008) Überlegungen zu waldbaulichen Strategien. Allg Forstzeitschrift 63:1104-1107

Wenk G, Römisch K, Gerold D (1985) DDR-Fichtenertragstafel 1984. Agrarwissenschaftliche Gesellschaft der DDR, Technische Universität Dresden - Sektion Forstwissenschaft, Tharandt

Wenk G, Antanaitis V, Smelko S (1990) Waldertragslehre. Deutscher Landwirtschaftsverlag, Berlin

Werner F, Taverna R, Hofer P, Richter K (2006) Greenhouse gas dynamics of an increased use of wood in buildings in Switzerland. Clim Change 74:319-347. doi:10.1007/s10584-006-0427-2

White MK, Gower ST, Ahl DE (2005) Life cycle inventories of roundwood production in northern Wisconsin: inputs into an industrial forest carbon budget. For Ecol Manage 219:13-28. doi:10.1016/j.foreco.2005.08.039

Wilhelm GJ, Letter H-A, Eder W (1999) Zielsetzung und waldbauliche Prinzipien. AFZ/DerWald 54:232-233

Winjum JK, Brown S, Schlamadinger B (1998) Forest harvests and wood products: sources and sinks of atmospheric carbon dioxide. For Sci 44:272-284

Wirth C, Schulze E-D, Schwalbe G, Tomczyk S, Weber G, Weller E (2004) Dynamik der Kohlenstoffvorräte in den Wäldern Thüringens. Mitteilungen der Thüringer Landesanstalt für Wald, Jagd und Fischerei, 23/2004. Thüringer Landesanstalt für Wald, Jagd und Fischerei, Gotha

Woodbury PB, Smith JE, Heath LS (2007) Carbon sequestration in the US forest sector from 1990 to 2010. For Ecol Manage 241:14-27. doi:10.1016/j.foreco.2006.12.008

Ximenes FA, Gardner WD, Cowie AL (2008) The decomposition of wood products in landfills in Sydney, Australia. Waste Manag. doi:10.1016/j.wasman.2007.11.006 